\title{
PENATAAN REGULASI \\ DALAM MENDUKUNG PEMBANGUNAN EKONOMI NASIONAL
}

\author{
(Regulatory Reform to Support National Economic Development)
}

\author{
Arfan Faiz Muhlizi \\ Pusat Analisis dan Evaluasi Hukum Nasional \\ Badan Pembinaan Hukum Nasional \\ Jl. Mayjen Sutoyo No.10 Cililitan Jakarta \\ Email: arfan_fm@yahoo.com
}

Naskah diterima: 15 Agustus 2017; revisi: 15 November 2017; disetujui: 15 November 2017

\begin{abstract}
Abstrak
Indonesia yang sedang membangun sistem perekonomian nasional menghadapi tantangan persaingan global. Pada situasi inilah maka terciptanya iklim kemudahan berusaha menjadi penting. Tulisan ini membahas pendekatan teoritis yang dapat digunakan untuk melakukan penataan hukum agar tidak mengganggu kemudahan berusaha dalam pembangunan ekonomi nasional, serta langkah-langkah yang dilakukan agar tidak terjadi tumpang tindih antara peraturan yang satu dengan peraturan yang lain. Dengan menggunakan pendekatan yuridis normatif disimpulkan bahwa pembangunan ekonomi nasional dengan pendekatan teori hukum integratif perlu dilakukan agar kebijakan yang dikeluarkan untuk memudahkan usaha dapat diimbangi dengan penguatan peran hukum yang bukan sekedar sebagai pemberi fasilitas kemudahan berusaha, tetapi juga memberikan perlindungan bagi persaingan usaha yang tidak sehat. Pemerintah perlu melakukan langkah evaluasi seluruh peraturan perundang-undangan, penguatan pembentukan peraturan perundangundangan, dan pembuatan database yang terintegrasi. Evaluasi peraturan perundang-undangan dilakukan mengingat kualitas regulasi saat ini masih rendah dengan masih adanya disharmoni antar peraturan perundang-undangan, baik yang bersifat vertikal maupun horizontal, serta tidak semuanya berdaya guna dan berhasil guna. Penguatan pembentukan peraturan perundang-undangan harus mampu mengontrol isu-isu primordial, sektarian, kepentingan asing, dan ego sektoral. Pembuatan database yang terintegrasi perlu dilakukan agar tersedia informasi yang akurat, mengenai status peraturan perundang-undangan, baik tingkat pusat maupun daerah dan merupakan sarana pendukung yang sangat vital bagi analisis dan evaluasi regulasi, harmonisasi, serta sinkronisasi peraturan perundang-undangan.

Kata Kunci: hukum ekonomi, teori hukum integratif, Pancasila, kemudahan berusaha, penataan regulasi
\end{abstract}

\begin{abstract}
Indonesia as developing country is facing challenges of global competition. In this situation, creating ease of doing business becomes important. This paper discusses what theoretical approach can be used to conduct regulatory reform so as not to interfere with the ease of doing business in national economic development and how the steps are carried out in order to avoid overlapping regulations. Using normative juridical approach, it is concluded that the national economic development can apply integrative law theory so that the policy issued to facilitate the business can be offset by strenghtening the role of law which is not just give unfair business facilities. Government needs to evaluate laws and regulations, also create an integrated database. Strengthening legislation should be able to control primordial, sectarian, foreign, and sectoral ego issues. Creating a database is important to provide accurate information about the status of laws and regulations, both central and regional levels. Legislation database rules are a vital support tool for regulatory analysis and harmonization. Keywords: economic law, integrative law theory, Pancasila, ease of doing business, regulatory reform
\end{abstract}




\section{A. Pendahuluan}

Erapersainganglobalmemaksasemua negara untuk berlomba membangun dan memperkuat sistem perekonomian masing-masing. Indonesia sebagai salah satu negara yang sedang berjuang menarik investasi sebesar-besarnya untuk membangun sistem perekonomian nasional menghadapi tantangan yang sama di tengah persaingan tersebut. ${ }^{1}$ Ketika dunia ini menjadi satu pasar berakibat pada semakin kuatnya interpedensi atau saling ketergantungan antara satu negara dengan negara lainnya yang samasama mempunyai kedaulatan nasional. Jadi yang sebenarnya terjadi bukanlah satu negara tergantung pada negara lainnya, melainkan suatu situasi dan kondisi di mana semuanya saling memerlukan untuk mempertahankan keseimbangan politis, ekonomis dan tentu pula dalam rangka pemenuhan kepentingan masing -masing negara ${ }^{2}$. Pada situasi inilah maka terciptanya iklim kemudahan berusaha (ease of doing business) di tiap negara menjadi penting. ${ }^{3}$

Dalam rangka merespon tantangan tersebut pemerintah Indonesia secara terus- menerus berupaya untuk menaikkan peringkat kemudahan berusaha. ${ }^{4}$ Upaya ini perlu diimbangi dengan penguatan peran hukum yang bukan sekedar sebagai pemberi fasilitas kemudahan berusaha, tetapi juga memberikan perlindungan bagi persaingan usaha yang tidak sehat di tengah iklim ekonomi dunia yang cenderung liberal agar tidak larut dalam pusaran pasar bebas. Oleh karena itu, Pemerintah harus memberikan proporsi yang wajar melalui sistem seleksi dan pengarahan yang adequate dengan kedaulatan tunggal yang dimiliki ${ }^{5}$. Regulasi yang dibangun harus mampu menyeimbangankan berbagai kepentingan agar masing-masing negara saling menghormati kedaulatan untuk menetapkan kebijakan hukum investasinya, namun masingmasing negara harus pula saling melindungi dan memperlakukan kegiatan investasi di negaranya tanpa ada diskriminasi antara investor asing dengan investor domestik, demikian juga antar sesama investor asing. Prinsip ini menekankan pada dasar pikiran prinsip perlindungan keseimbangan kepentingan antar masing-

Kondisi ini dengan tepat digambarkan Daniel Davidson: "We are so economicially interdependent on one another that We so live in global village". Lebih jauh lihat CFG Sunaryati Hartono, Globalisasi dan Perdagangan Bebas, (Jakarta: BPHN Departemen Kehakiman, 1996), hlm. 12

2 Rusdin. Bisnis Internasional dalam Pendekatan Praktik. Jilid 1. (Bandung: Alfabeta, 2002), hlm. 34.

3 Meningkatnya perekonomian di banyak negara ini menciptakan derajat keterbukaan ekonomi yang semakin tinggi di dunia, yang terlihat bukan hanya pada arus peningkatan barang tapi juga pada arus jasa serta arus uang dan modal. Pada gilirannya arus investasi di dunia semakin mengikuti perkembangan ini, sehingga dewasa ini peningkatan arus investasi itulah yang memacu arus perdagangan di dunia. Lebih jauh lihat Yanto Bashri (ed). "Mau Ke Mana Pembangunan Ekonomi Indonesia. Prisma Pemikiran Prof. Dr. Dorodjatun Kuntjoro-Jakti. (Jakarta: Predna Media, 2003), hlm. 12-13.

4 Bank Dunia (World Bank) mengumumkan lewat laporan tahunan terbarunya bahwa Indonesia berhasil masuk menjadi 10 negara dunia yang mencapai peningkatan kemudahan berusaha (Ease of Doing Business/EoDB). Laporan yang bertajuk "Doing Business 2017: Equal Opportunity" yang diluncurkan di Washington DC (25/10) mengungkapkan bahwa Indonesia naik 15 peringkat, dari posisi ke-106 menjadi posisi ke-91, di tahun 2016. Lihat http://www.bkpm.go.id/id/artikel/readmore/usaha-pemerintah-indonesia-dalam-meningkatkankemudahan-berusaha, (diakses 8 Agustus 2017).

5 Bandingkan dengan B. Napitupulu. Joint Ventures di Indonesia. (Jakarta: Erlangga, 1975), hlm. 30. 
masing pihak dengan saling menghormati dan memberikan perlakuan tanpa diskriminasi ${ }^{6}$.

Meskipun penciptaan iklim kemudahan berusaha ini selalu dikaitkan dengan upaya untuk membangun ekonomi nasional, namun harus tetap dijaga agar pembangunan yang dilakukan tidak terjerumus pada pembangunan sebagai sekedar konsep developmentalisme yang sempit. ${ }^{7} \quad$ Pembangunan ekonomi merupakan proses yang diselenggarakan secara berkelanjutan untuk mencapai kemakmuran dan kemajuan bangsa. Sebagai bagian integral dari pembangunan nasional, perwujudan tujuan di atas tercermin di dalam peningkatan kegiatan ekonomi yang disertai dengan perbaikan kualitas hidup setiap penduduknya sebagaimana diamanatkan Pasal 33 UUD NRI 1945. Hal ini mensyaratkan adanya kegiatan perekonomian yang secara berkelanjutan meningkat kualitas dan kuantitasnya, stabilitas ekonomi yang terjaga, dan hasil dari pembangunan ekonomi yang dinikmati secara nyata oleh seluruh masyarakat.

Agenda pembangunan bidang ekonomi pada dasarnya merupakan refleksi dari citacita kemerdekaan dan Pancasila. Dalam konteks ini, Pancasila harus dimaknai secara utuh di mana sila-silanya tidaklah terlepas satu dengan yang lain. Kelima sila Pancasila bersifat saling memaknai dan merupakan satu kesatuan yang utuh ${ }^{8}$. Pemaknaan yang utuh ini dapat dimulai dari sila ke-3 yang menunjukkan tonggak kesadaran bangsa Indonesia untuk bersepakat mendapatkan kemerdekaannya dan kemudian mewujudkan keinginan bersama setelah merebut kemerdekaan itu sebagai satu bangsa. Satu-satunya cara untuk mewujudkan keinginan bersama itu adalah dengan adanya persatuan. Persatuan di sini bukan berarti menghilangkan keberagaman tetapi justru dibangun dalam prinsip bhinneka tunggal ika di mana perbedaan-perbedaan yang ada dikelola

$6 \quad$ Prinsip-prinsip penanaman modal asing yang meliputi non discriminatory principle, yang berintikan The Most Favoured Nation (MFN) Treatment Principle dan National Treatment Principle, juga tentang Perkecualian terhadap MFN dan National Treatment serta Transparency Principle. Lebih jauh lihat Muchammad Zaidun, Prinsip-prinsip Hukum Internasional Penanaman Modal Asing di Indonesia, (Ringkasan Disertasi), Program Pasca Sarjana Universitas Airlangga, 2005, hlm.17-20.

7 Mansour Fakih mengungkapkan bahwa pembangunan merupakan konsep yang lahir dari pertentangan yang panjang antara ideologi Kapitalisme dan Sosialisme. Konsep development tidak lebih merupakan refleksi paradigma Barat tentang perubahan sosial, yakni langkah-langkah menuju "higher modernity". Modernitas diterjemahkan dalam bentuk teknologi dan pertumbuhan ekonomi mengikuti jejak negara-negara industri yang mengacu pada revolusi industri. Pembangunan selanjutnya lebih dimaksud demi peningkatan standar hidup , dan itu hanya bisa ditempuh melalui industrialisasi. Pemerintah dalam perspektif ini adalah sebagai subyek yang tugasnya mentransformasikan rakyat menjadi objects, recipients, clients atau participant. Modernisasi selanjutnya menjadi dasar developmentalisme. Kata modernisasi juga berkonotasi sekularisasi, industrialisasi, persatuan nasional serta partisipasi massa. Asumsi dasar modernisasi adalah bahwa tradisi adalah "masalah" (yang harus diselesaikan) dan harus ditransformasi, seperti apa yang dialami Eropa dulu. Dalam kenyataannya modernisasi dan developmentalisme tidak berbeda dengan kapitalisme. Konsep developmentalisme semacam ini tentu tidak bisa begitu saja secara mentah-mentah diadopsi untuk diterapkan di Indonesia yang mempunyai sejarah dan struktur budaya yang berbeda dengan masyarakat Barat. Lebih jauh lihat Mansour Fakih, Tinjauan Kritis Terhadap Revolusi Hijau, dalam Hatta Sunanto et.all, Menggeser Pembangunan Memperkuat Rakyat, Emansipasi dan Demokrasi Mulai dari Desa, (Yogyakarta: Lapera Pustaka Utama, 2000), hlm. 4

8 Pocut Eliza dkk, Dokumen Pembangunan Hukum Nasional Tahun 2016, (Jakarta: BPHN, 2016), hlm. 4410 Soerdjono Soekanto, Pengantar Penelitian Hukum, (Jakarta: UI Press, 1986), hlm. 132. 
sedemikian rupa sehingga menjadi kekuatan untuk bergerak bersama mencapai tujuan yang dicita-citakan. Tujuan bersama ini mengacu pada sila ke-5 yaitu keadilan sosial bagi seluruh rakyat Indonesia. Tujuan bangsa Indonesia bersatu adalah untuk mencapai keadilan dan kesejahteraan masyarakat. Kemudian, untuk mencapai cita-cita itu harus ada sebuah mekanisme pemerintahan. Mekanisme di sini bukan hanya untuk memilih atau mengisi jabatan-jabatan pemerintahan itu tetapi juga mekanisme untuk menjalankannya. Mekanisme yang dipilih bangsa Indonesia ini dinyatakan oleh sila ke-4 yaitu demokrasi. Proses kerja pemerintahan yang demokratis serta kehidupan berbangsa dan bernegara ini harus senantiasa berlandaskan nilai-nilai yang terkandung dalam sila ke-1 dan sila ke-2 Pancasila. Nilai-nilai ketuhanan dan kemanusiaan harus senantiasa menjiwai pelaksanaan demokrasi dalam rangka mencapai masyarakat yang adil dan makmur.

Hanya saja pada tataran implementasi, banyak permasalahan yang perlu ditemukan solusinya baik dari perspektif ekonomi maupun dalam perspektif hukum. Dalam Hukum Ekonomi ${ }^{9}$ permasalahan utama yang dihadapi adalah mudah sekali terjadi tumpang tindih atau bahkan pertentangan (kontradiksi) antara peraturan yang satu dengan peraturan yang lain. ${ }^{10}$ Padahal hal ini merupakan pelanggaran yang besar dalam kegiatan penyusunan peraturan perundang-undangan (legis/ation). Pertentangan atau inkonsistensi dalam perundang-undangan itu merusak seluruh sistem hukum, karena mengakibatkan ketidakpastian hukum dan hilangnya benang merah politik hukum yang telah ditentukan sebelumnya. Selain itu masalah yang dihadapi

$9 \quad$ Istilah 'Hukum Ekonomi' yang digunakan di sini dipengaruhi dari istilah yang sering digunakan dalam beberapa literatur negara-negara Barat, seperti Economic Law (E.C.A.M. Boot, Introduction to Dutch Law for Lawyers, Kluwer, Deventer, 1978), Economisch Recht (M.R. Mok, "Economic Recht Droit", dalam W.F. de Gaay Fortman, Problemen van Wetgeving, Kluwer Deventer, 1982), dan istilah yang digunakan oleh badan Pembinaan Hukum Nasional. Di Amerika Serikat istilah yang digunakan bukan 'Hukum Ekonomi' tapi Economic and Law (A. Mitchell Polinsky, an Introduction to Law and Economic, Boston and Toronto, Little Brown and Company, 1983) atau Business Law (Mark E. Roszkowski, Business Law, New York, Mc.Graw-Hill Publishing Company, 1990). Istilah dari Amerika tersebut juga digunakan oleh beberapa pakar hukum Indonesia, seperti T. Mulya Lubis dalam bukunya Hukum dan Ekonomi, Jakarta, Pustaka Sinar Harapan, 1997. Hukum ekonomi diartikan keseluruhan peraturan-perundangan, hukum kebiasaan, putusan pengadilan yang berkaitan dengan kegiataan ekonomi, baik itu menyangkut badan hukum pelaku ekonomi, transaksi pelaku ekonomi, tempat transaksi pelaku ekonomi, sampai dengan intervensi pemerintah untuk menunjang kegiatan ekonomi, dan mekanisme penyelesaian sengketa pelaku ekonomi. Sedangkan menurut C.F.G. Sunaryati Hartono, hukum ekonomi dalam arti luas adalah keseluruhan kebijaksanaan dan peraturan hukum yang tidak hanya terbatas pada Hukum Administrasi Negara, tetapi juga mengatur hal-hal yang termasuk substansi Hukum Pidana, Hukum Perdata, Hukum Dagang, Hukum Perdata Internasiona, bahkan hukum acara perdata dan pidana. Sunaryati Hartono, "Upaya Menyusun Hukum Ekonomi Indonesia Pasca tahun 2003", Makalah dalam Seminar Pembangunan Nasional VIII, Tema Penegakkan Hukum Dalam rangka Pembangunan Berkelanjutan, Diselenggarakan Badan Pembinaan Hukum Nasional Departemen Kehakiman dan Hak Asasi Manusia, Denpasar, 14-18 Juli 2003. Lebih jauh lihat juga Adi Sulistyono, Pembangunan Hukum Ekonomi Untuk Mendukung Pencapaian Visi Indonesia 2030, Makalah disampaikan pada Pidato Pengukuhan Guru Besar Hukum Ekonomi dalam Sidang Senat Terbuka Universitas Sebelas Maret Surakarta, 17 Nopember 2007.

10 Ahm/YK/WP, Tumpang-Tindih Regulasi Hambat Kemudahan Usaha, http://www.koran-jakarta.com/tumpangtindih-regulasi-hambat-kemudahan-usaha/ (diakses 8 Agustus 2017); Lihat juga Ibnu Hariyanto. Menkum HAM Ungkap Penyebab Banyak UU Masih Tumpang Tindih, https://news.detik.com/berita/d-3334692/menkum-ham-ungkappenyebab-banyak-uu masih- tumpang-tindih (diakses 8 Agustus 2017) 
adalah pembatasan hukum dan pembebanan secara berlebihan berbagai izin yang disyaratkan sebelum melakukan kegiatan-kegiatan ekonomi (deregulasi).

Permasalahan tersebut dapat diklasifikasikan sebagai permasalahan legislasi dan terkait langsung dengan penataan substansi hukum, di samping masih terdapat permasalahan implementasi yang tidak dapat dilepaskan dari struktrur dan budaya hukum. Tulisan ini akan lebih banyak membahas aspek legislasi dan hal-hal yang terkait dengan substansi hukum, sehingga permasalahanutamayangakandijawab dalam tulisan ini adalah bagaimana pendekatan teoritis yang dapat digunakan untuk melakukan penataan hukum dalam rangka penataan regulasi yang mendukung pembangunan ekonomi nasional? Serta bagaimana langkahlangkah yang dilakukan dalam rangka penataan regulasi agar tidak terjadi tumpang tindih atau bahkan pertentangan (kontradiksi) antara peraturan yang satu dengan peraturan yang lain?

\section{B. Metode Penelitian}

Berdasarkan permasalahan dan latar belakang di atas, penelitian ini dilakukan dengan menggunakan pendekatan yuridis normatif. ${ }^{11}$ Sebagai suatu penelitian yuridis normatif, maka penelitian ini berbasis pada analisis terhadap norma hukum, baik hukum dalam arti law as it is written in the books and statutes (dalam literatur dan peraturan- perundang-undangan). ${ }^{12} \quad$ Referensi juga diperoleh dari dokumen lain yang terkait seperti hasil penelitian sebelumnya, seminar dan/atau lokakarya, buku-buku dan jurnal ilmiah yang terkait, serta data dari berbagai media, baik cetak maupun elektronik. Tradisi penelitian dengan menggunakan laporan media massa, khususnya surat kabar dan internet, semakin berkembang pesat selama beberapa dasawarsa terakhir, terutama di bidang kajian tindakan kolektif dan gerakan sosial.

\section{Pembahasan}

\section{Pendekatan Hukum Integratif Untuk Mengeliminir Regulasi yang Menghambat Pembangunan Ekonomi.}

Dasar pengembangan hukum ekonomi adalah Pasal 33 UUD NRI 1945 hasil Amandemen Keempat mengatakan:

(1) Perekonomian disusun sebagai usaha bersama berdasar atas asas kekeluargaan;

(2) Cabang-cabang produksi yang penting bagi negara dan yang menguasai hajat hidup orang banyak dikuasai oleh negara;

(3) Bumi dan air dan kekayaan alam yang terkandung di dalamnya dikuasai oleh negara dan dipergunakan untuk sebesarbesar kemakmuran rakyat;

(4) Perekonomian nasional diselenggarakan berdasar atas demokrasi ekonomi dengan prinsip kebersamaan, efisiensi, berkeadilan, berkelanjutan, berwawasan lingkungan, kemandirian, serta dengan menjaga

11 Penelitian normatif adalah penelitian yang dilakukan dengan cara meneliti bahan pustaka atau data sekunder belaka. Pemikiran normatif didasarkan pada penelitian yang mencakup (1)asas-asas hukum, (2) sistematik hukum, (3) taraf sinkronisasi vertikal dan horisontal, (4)perbandingan hukum, (5)sejarah hukum. Lebih jauh tentang ini lihat Soerjono Soekanto dan Sri Mamudji, Peranan dan Penggunaan Perpustakaan di Dalam Penelitian Hukum, (Jakarta: Pusat Dokumentasi Hukum Fakultas Hukum Universitas Indonesia, 1979) hlm.15.

12 Lebih jauh lihat Ronald Dworkin, Legal Research, (Daedalus: Spring,1973), hlm. 250. 
keseimbangan kemajuan dan kesatuan ekonomi nasional;

(5) Ketentuan lebih lanjut mengenai pelaksanaaan pasal ini diatur dalam undangundang.

Ayat 5 dari pasal 33 UUD 1945 ini menandakan bahwa bukanlah hukum yang harus senantiasa mengikuti saja apa yang dihendaki oleh pemerintah sebagai politik dan kebijakan nasional kita, tetapi juga bahwa penentuan politik dan kebijakan ekonomi juga harus tunduk pada ketentuan dan asas-asas hukum yang telah ditentukan oleh UUD dan TAP MPR, serta masih akan ditentukan oleh undangundang dan peraturan perundang-undangan lain di masa depan. Untuk dapat menyusun undangundang atau peraturan perundang-undangan lainnya serta untuk dapat memutus perkara pengadilan atau arbitrase juga mengadakan negosiasi yang akan menghasilkan suatu dokumen hukum ekonomi, sarjana hukum harus mengerti dan memahami masalah-masalah ekonomi lokal, nasional dan internasional untuk dapat menghasilkan produk hukum ekonomi yang baik dan benar. Hal ini penting dilakukan untuk menetapkan politik dan kebijakan ekonomi yang sesuai dengan asas-asas Hukum nasional dan asas-asas umum pemerintahan yang baik (good governance), asas-asas hukum nasional mau pun ketentuan-ketentuan hukum ekonomi yang sudah berlaku sebelumnya.
Daniel S.Lev ${ }^{13}$ mempertegas pandangan ini dengan menyatakan bahwa negara hukum merupakan sine qua non, karena tanpa proses hukum yang efektif, tidak mungkin diharapkan perbaikan ekonomi, politik, kehidupan, sosial, dan keadilan. Hukum merupakan sarana yang penting untuk memelihara ketertiban dan sekaligus pembaharuan masyarakat sehingga harus dikembangkan sedemikian rupa agar dapat memberi ruang gerak bagi perubahan (tempora mutantur, nos et mutamur in Illis), ${ }^{14}$ dan bukan sebaliknya, menghambat usahausaha pembaruan karena semata-mata ingin mempertahankan nilai-nilai ortodoks. ${ }^{15}$

Sejalan dengan hal tersebut maka negara perlu membentuk suatu iklim usaha yang dapat memudahkan usaha dan meminimalkan risiko berusaha. Dari sekian banyak risiko yang timbul dalam upaya tersebut, terdapat dua risiko utama yang akan menjadi patokan awal, yaitu risiko politis dan risiko pengaturan. Risiko politis timbul bilamana tidak ada kejelasan fungsi/peran dari pemerintah, sementara risiko pengaturan timbul karena adanya penyalahgunaan fungsi/peran dari pengaturan itu sendiri. ${ }^{16}$ Pada dasarnya kedua resiko ini dapat dieliminasi dengan menggunakan pendekatan hukum integratif.

Teori hukum integratif memberikan pencerahan mengenai relevansi Pancasila dan arti penting hukum dalam kehidupan manusia Indonesia, dan mencerminkan bahwa hukum

13 Daniel S.Lev., "Pemulihan Negara Hukum”, Tempo, 6 Januari 2002.

14 Tempora mutantur, nos et mutamur in Illis merupakan ungkapan Latin yang memiliki makna "zaman berubah dan kita juga berubah bersamanya". Lebih jauh tentang ini lihat Barita Saragih, Tantangan Hukum atas Aktivitas Internet, Kompas, Minggu, 9 Juli 2000, hlm. 8.

15 Lebih jauh tentang ini lihat Pidato Kepala Negara RI pada pelantikan Menteri Kehakiman pada tanggal 19 Januari 1974 dalam Mochtar Kusumaatmadja, Konsep-konsep Hukum Dalam Pembangunan, (Bandung: Alumni, 2002) hlm.74 .

16 Bandingkan dengan Adrian Sutedi, Hukum Perizinan Dalam Sektor Pelayanan Publik, cetakan ketiga, (Jakarta: Sinar Grafika, 2015), hlm. 66. 
sebagai sistem yang mengatur kehidupan masyarakat tidak dapat dipisahkan dari kultur dan karakter masyarakatnya serta letak geografis lingkungannya serta pandangan hidup masyarakat. ${ }^{17}$ Keyakinan teori hukum integratif adalah fungsi dan peranan hukum sebagai sarana pemersatu dan memperkuat solidaritas masyarakat dan birokrasi dalam menghadapi perkembangan dan dinamika kehidupan, baik di dalam lingkup Negara Kesatuan Republik Indonesia (NKRI), maupun di dalam lingkup perkembangan internasional. ${ }^{18}$ Peran birokrasi menempati posisi penting dalam teori integratif. Oleh karena itu upaya untuk mengubah atau merekayasa birokrasi yang mempermudah iklim usaha menjadi sangat penting untuk dilakukan. Selanjutnya birokrasi memberikan dan melaksanakan keteladanan sesuai dengan ketentuan yang berlaku dan diharapkan masyarakat mematuhi dan mengikuti langkahlangkah penyelenggara birokrasi tersebut. Hal ini dapat dilaksanakan secara efektif jika penyelenggara birokrasi telah memahami fungsi dan peranan serta posisi hukum sebagaimana berikut: ${ }^{19}$

1. Hukum dipandang bukan sebagai perangkat yang harus dipatuhi oleh masyarakat saja melainkan juga harus dipandang sebagai sarana yang harus dapat membatasi perilaku aparat penegak hukum dan pejabat publik;
2. Hukum bukan hanya diakui sebagai $a$ tool of social engineering semata-mata tetapi juga harus diakui sebagai a tool of social control and beureucratic engineering;

3. Kegunaan atau kemanfaatan hukum tidak lagi hanya dilihat dari kacamata kepentingan pemegang kekuasaan melainkan harus juga dikaji dari prospektif dan perspektif kepentingan stakeholder;

4. Fungsi hukum sebagai sarana pembaharuan sosial dan birokrasi dalam kondisi masyarakat yang bersifat vulnerable dan transitional, tidak dapat dilaksanakan secara optimal hanya menggunakan pendekatan preventif dan represif semata-mata melainkan juga memerlukan pendekatan restoratif, dan rehabilitatif;

5. Agar fungsi dan peranan hukum dapat dilaksanakan secara optimal maka hukum tidak semata-mata dipandang sebagai wujud dari komitmen politik, melainkan harus dipandang sebagai sarana untuk merubah sikap (attitude) dan perilaku (behavior).

Dengan menempatkan peran dan fungsi hukum sebagaimana di atas maka hukum diharapkan mampu menciptakan "stability", "predictability" dan "fairness". ${ }^{20}$ Dua hal yang pertama adalah prasyarat bagi berfungsinya sistem ekonomi yang baik. Fungsi stabilitas

17 Romli Atmasasmita, Teori Hukum Integratif: Rekonstruksi Terhadap Teori Hukum Pembangunan dan Teori Hukum Progresif, (Yogyakarta: Genta Publishing, 2012) hlm. 97-98.

18 Ibid.

19 Romli Atmasasmita, Pengantar Hukum Kejahatan Bisnis, (Jakarta: Prenada Media, 2003), hlm.20-21

20 Secara umum dapat dikatakan bahwa hukum mempunyai fungsi sebagai perlindungan kepentingan manusia. Agar kepentingan manusia terlindungi, hukum harus dilaksanakan. Pelaksanaan hukum dapat berlangsung secara normal, damai, tetapi dapat juga terjadi karena adanya pelanggaran hukum. Dan, hukum yang terlanggar tersebut tentunya harus ditegakkan. Hanya melalui penegakkan hukum inilah tujuan hukum bisa menjadi kenyataan. Dan, untuk menegakkan hukum terdapat tiga unsur yang harus selalu diperhatikan, yaitu: kepastian hukum (rechtssicherheit), kemanfaatan (zweck-massigkeit) dan keadilan (gerechtigkeit). Lebih jauh lihat Sudikno Mertokusumo dan A. Pitlo, Bab-bab tentang Penemuan Hukum, (Yogyakarta: Citra Adtya Bakti, 1993) , hlm 1 
(stability) di antaranya adalah potensi hukum menyeimbangkan dan mengakomodasi kepentingan-kepentingan yang saling bersaing. Kebutuhan fungsi hukum untuk dapat meramalkan (predictability) akibat dari suatu langkah-langkah yang diambil. Aspek keadilan (fairness), seperti, perlakuan yang sama dan standar pola tingkah laku Pemerintah adalah perlu untuk menjaga mekanisme pasar dan mencegah birokrasi yang berlebihan. Sehingga melalui sistem hukum dan peraturan hukum yang dapat memberikan perlindungan, akan tercipta kepastian (predictability), keadilan (fairness) dan efisiensi (efficiency) bagi para investor untuk menanamkan modalnya. ${ }^{21}$

Pemerintah sebagai regulator dan fasilitator pembangunan ekonomi bertanggung jawab terhadap menarik atau tidaknya iklim berusaha di Indonesia. Ini berarti bahwa kurang menariknya iklim berusaha mengindikasikan lemahnya kapasitas pemerintah dalam mendorong daya saing negeri ini. Dalam konteks ini, kelemahan tersebut, diindikasikan oleh: pertama, ketidakmampuan pemerintah untuk membendung impor produk illegal. Kedua, kurangnya koordinasi antar instansi pemerintah baik di level pusat, daerah dan antar daerah. Kondisi ini kian diperumit oleh lemahnya kepemimpinan ataupun profesionalisme kerja birokrat serta masih kentalnya intervensi kepentingan kelompok dalam pengambilan kebijakan ekonomi. Ketiga, kurangnya inisiatif pemerintah untuk melibatkan partisipasi kelompok asosiasi ataupun profesional secara nyata dalam perumusan kebijakan ekonomi serta dalam memonitor implementasi kebijakan, dan juga dalam menindaklanjuti/memecahkan penyimpangan kebijakan. Keempat, komitmen yang rendah dalam mengimplementasikan grand design/strategi dan road map pembangunan ekonomi nasional ${ }^{22}$.

Penggunaan teori hukum integratif dapat dijadikan sebagai desain solutif atas berbagai permasalahan di atas serta mengikat ${ }^{23}$ tujuan pembangunan hukum ekonomi, terutama untuk menciptakan iklim kemudahan berusaha atau yang lebih dikenal sebagai ease of doing business $(\mathrm{EODB})^{24} \mathrm{di}$ Indonesia sebagaimana gambar berikut:

21 Erman Radjagukguk, Hukum Investasi di Indonesia, (Jakarta: FH Univ Al Azhar Indonesia, cetakan pertama, 2007), hlm. 27-31.

22 Hadi Subhan, mengutip Latif Adam, Prioritas Pengembangan Hukum Di Bidang Investasi, makalah pada harmonosasi dan sinkronisasi BPHN, Oktober 2008.

23 Peran pengikat ini penting karena secara teoritik sistem hukum adalah suatu kesatuan yang utuh yang terdiri dari unsur-unsur yang satu sama lain saling berhubungan dan kait mengait secara erat. Dengan demikian untuk mencapai suatu tujuan hukum dalam satu kesatuan diperlukan kesatuan sinergi antara unsur-unsur yang terdapat dalam sistem tersebut. Lebih jauh lihat Soedikno Mertokusumo, Mengenal Hukum: Suatu Pengantar, Cetakan Kedua, Edisi ke empat, (Yogyakarta: Penerbit Liberty, 1999) hlm, 115-116. Bandingkan juga dengan L M Gandhi dan Lily Mulyati, Sejarah Tata Hukum Indonesia dan Sistem Hukum Indonesia, dalam E Fernando M Manullang (editor), Selayang Pandang Sistem Hukum di Indonesia, Cetakan ke 2, (Jakarta: Penerbit Kencana, 2016) hlm. 45.

24 EODB dimaknai sebagai kemudahan berusaha dilihat dari 10 kriteria yaitu: Getting Credit, Resolving Insolvency, Getting Electricity, Paying Tax, Enforcing Contract, Protecting Minority Investors, Registering property, Trading Across Borders, Dealing with Construction Permit, Starting Business. Lebih jauh lihat http://eodb.ekon.go.id/ dikases pada 17 Juni 2017. 


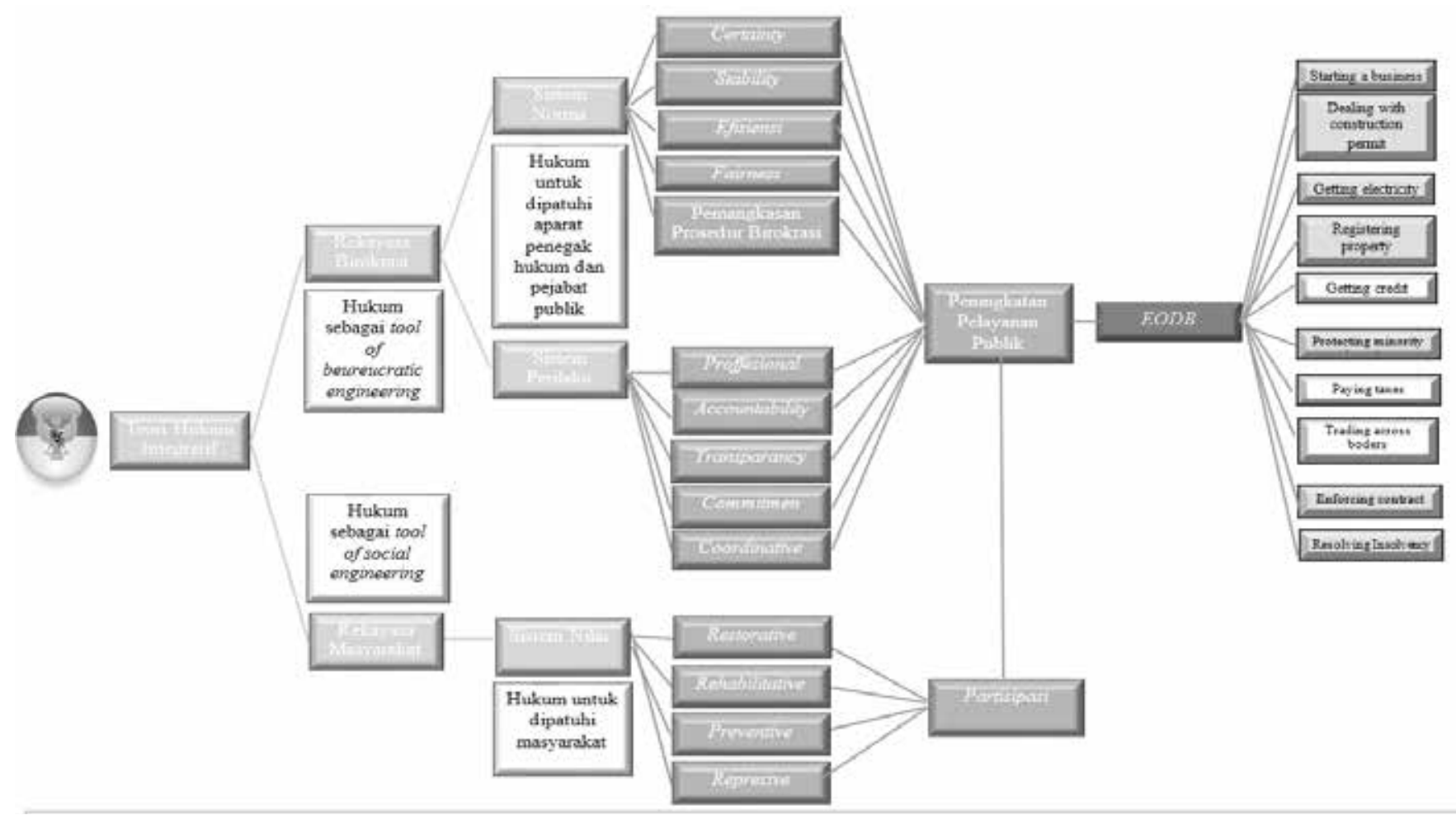

Gambar 1. Pengembangan Teori Hukum Integratif Dalam Mendukung EODB

Sumber: Adopsi dari Romli Atmasasmita, Teori Hukum Integratif: Rekonstruksi Terhadap Teori Hukum Pembangunan dan Teori Hukum Progresif, I (Yogyakarta: Genta Publishing, 2012), hlm. 123.

Pada gambar di atas terlihat bahwa teori hukum integratif menempatkan Pancasila sebagai bintang pemandu agenda penataan regulasi untuk menciptakan ease of doing business agar tidak menabrak nilai-nilai dasar kehidupan berbangsa dan bernegara, dan menjaga agar tidak tumbuh menjadi sistem ekonomi liberal ${ }^{25}$. Upaya untuk menjaga agar penciptaan EODB tetap pada rel konstitutif ini dapat dilakukan dengan selalu memperhatikan tujuh ciri konstitusional pembangunan ekonomi sebagai berikut: ${ }^{26}$ Pertama, perekonomian bertujuan untuk mencapai kemakmuran bersama seluruh rakyat, hal ini secara eksplisit dijelaskan dalam penjelasan Pasal 33 UUD 1945. Kedua, keikutsertaan rakyat dalam pemilikan, proses produksi dan menikmati hasilnya. Hal ini sesuai dengan rumusan yang terdapat dalam Pasal 33 ayat (1) dan ayat (4) UUD 1945. Ketiga, sesuai dengan prinsip Pasal 33 ayat (4) UUD 1945 yaitu efisiensi berkeadilan, perekonomian perlu dijalankan dengan menggunakan mekanisme pasar yang berkeadilan yang didasarkan pada persaingan yang sehat dan

25 Sistem ekonomi liberal cenderung melihat dunia sebagai satu kesatuan pemikiran, sikap, dan nilai (one world). Sedangkan Pancasila memegang paham "berbeda-beda dalam satu kesatuan." Pandangan globalisasi sebagai sistem dunia di segala bidang tidak realistik dan rentan terhadap konflik sosial dan budaya, bahkan dapat mempengaruhi pembentukan dan penegakan hukum. Hal ini menuntut revitalisasi Pancasila sebagai langkah yang tidak terelakkan sebagai sistem nilai tertinggi di dalam piramida sistem hukum di Indonesia. Lebih jauh lihat Romli Atmasasmita, Pengantar Hukum Kejahatan Bisnis, (Jakarta: Prenada Media, 2003) hlm. 100-101.

26 Subiakto Tjakrawerdaja, Menunggu UU Induk Mengenai Perekonomian Nasional, Reform Review (Jurnal untuk Kajian dan Pemetaan Krisis), Volume II Nomor 1 April-Juni 2008, hlm. 40. 
peranan serta kewenangan negara untuk intervensi jika terjadi kegagalan pasar. Keempat, peran Negara harus dijamin, sebagaimana diamanatkan Pasal 33 ayat (1) dan ayat (3) UUD 1945 terutama dalam hal perencanaan ekonomi nasional, dalam membentuk dan menegakkan pelaksanaan Undang-undang, dan dalam hal melaksanakan program pelayanan dan pemberdayaan masyarakat, pembebasan pajak, pemberian subsidi dan lainnya. Kelima, BUMN sebagai salah satu soko guru kegiatan ekonomi menguasai cabang-cabang produksi yang penting dan yang menguasai hajat hidup orang banyak. Hal ini jelas tertuang dalam Pasal 33 ayat (2) UUD 1945. Keenam, koperasi sebagai soko guru perekonomian rakyat harus diwujudkan dalam semangat kebersamaan dengan BUMN dan swasta, serta sebagai badan usaha ekonomi rakyat. Ketujuh, perekonomian nasional haruslah merupakan perwujudan dari kemitraan yang sejajar antara koperasi, BUMN dan swasta. Prinsip ini termuat dalam Pasal 33 ayat (1) UUD 1945. Ciri-ciri konstitusional inilah yang semestinya diterjemahkan dalam seluruh rangkaian penataan regulasi dalam rangka mendukung pembangunan ekonomi nasional. ${ }^{27}$

\section{Langkah Penataan Regulasi Dalam Mewujudkan Agenda Pembangunan Ekonomi.}

Salah satu alasan pentingnya dilakukan penataan regulasi di Indonesia adalah: ${ }^{28}$ 1) Terlalu banyaknya regulasi (Hyper-regulation) ${ }^{29}$; 2) Saling bertentangan (Conflicting) ${ }^{30}$; 3) Tumpang tindih (Overlapping) ${ }^{31}$; 4) Multi tafsir (Multi Interpretation) ${ }^{32}$; 5) Tidak taat

\section{Ibid. hlm.41}

28 DAPP-BAPPENAS, "Pemetaan Hasil Identifikasi terhadap undang-undang Sektor yang Berpotensi Bermasalah", disampaikan pada workshop koordinasi strategis analisa peraturan perundang-undangan Jakarta, 5 Desember 2012. Pemataan dilakukan oleh 10 direktorat dan lingkungan bappenas serta 21 undang -undang yang dilakukan secara self-assessment. Bandingkan dengan Ida Bagus Rahmadi Supancana, Sebuah Gagasan Tentang Grand Design Reformasi Regulasi Indonesia, (Jakarta: Penerbit Universitas Katolik Indonesia Atma Jaya, 2017) hlm. 2-4.

29 Meskipun tidak diketahui secara pasti tentang total jumlah regulasi di Indonesia, baik pada tingkat Pusat, Provinsi, maupun Kabupaten dan Kota, setidak-tidaknya sampai dengan level peraturan daerah dan peraturan Menteri/Lembaga, terdapat sejumlah kurang lebih 60.000 peraturan. Jumlah tersebut belum termasuk peraturan pelaksanaan setingkat Direktur Jenderal atau yang setingkat. Banyaknya regulasi tersebut telah menimbulkan gurauan (joke) yang menyatakan bahwa jika dulu di Indonesia terkenal dengan "hukum rimba", maka kondisi yang kita hadapi sekarang adalah "rimba hukum". Betapa menyedihkan karena regulasi sudah tidak lagi menjadi solusi, tetapi malahan menjadi beban.

30 Yang kurang menggembirakan,data menunjukan bahwa masih banyak peraturan perundang-undangan yang mempunyai materi muatan yang bertentangan, baik yang sifatnya vertikal, maupun horizontal. Akibatnya menimbulkan kegamangan ketidakpastian dalam pelaksanaannya

31 Masih banyak juga peraturan yang bersifat tumpang tindih, artinya untuk isu yang sama diatur oleh banyak peraturan perundang-undangan. Bahkan dalam satu Kementrian/Lembaga terdapat beberapa peraturan untuk mengatur isu yang sama.

32 Permasalahan lain dibidang regulasi adalah banyaknya ketentuan regulasi yang mengandung materi muatan yang bersifat multi tafsir. Akibat dari peraturan yang bersifat multi tafsir adalah disamping mengandung ketidakpastian dan perbedaan dalam implementasinya, juga rentan akan kemungkinan di salah gunakan untuk kepentingan tertentu. 
asas (Inconsistency) ${ }^{33}$; 6) Tidak efektif ${ }^{34}$; 7) Menciptakan beban yang tidak perlu (Unnecesarry Burden) ${ }^{35}$; 8) Menciptakan Ekonomi Biaya Tinggi (High-Cost Economy) ${ }^{36}$.

Untuk mengatasi permasalahan yang sedang dihadapai saat ini, Presiden Jokowi pada Rapat terbatas di Kantor Presiden tanggal 7 Januari 2017 menegaskan agar reformasi hukum tidak hanya menyentuh sektor hilir yang terkait pelayanan publik, tetapi juga menyentuh sektor hulu yang terkait dengan pembenahan regulasi, prosedur, dan penataan regulasi yang harus menjadi prioritas reformasi hukum saat ini $^{37}$. Regulasi harus sinkron satu sama lain dan sejalan dengan Pancasila, UUD NRI Tahun 1945, serta kepentingan nasional. Regulasi yang tidak sinkron, tumpang tindih, dan membuat segala sesuatunya menjadi berbelit, itu harus dievaluasi. Regulasi harus sederhana, tetapi memiliki kekuatan yang mengikat ${ }^{38}$. Pembentukan regulasi baru tidak boleh lagi dilihat sebagai proyek tahunan, tetapi benarbenar harus diperhatikan aturan itu memiliki landasan yang kuat secara konstitusional dan pembenahan regulasi ini dapat memanfaatkan teknologi yang $\operatorname{ada}^{39}$ dalam mendukung pembangunan nasional.

Hal ini perlu dilakukan untuk membentuk sebuah pemerintahan yang baik (Good governance). Pemerintahan yang baik setidaktidaknya harus didukung tiga faktor yang mesti

33 Ketidaktaatan asas dalam regulasi di Indonesia juga menonjol, terutama terkait dengan hubungan antara kebijakan dengan regulasi. Dalam banyak regulasi ditemukan bahwa regulasi tersebut tidak konsisten dengan kebijakan yang membesarinya. Padahal sebagaimana dipahami bahwa regulasi merupakan instrumen kebijakan. Ketidak taatan asas juga nampak pada berbagai terminologi yang digunakan, termasuk pengertiannya. Hal ini akan membingungkan berbagai pihak yang mendasarkan tindakannya pada peraturan-peraturan tersebut.

34 Pada banyak regulasi ditemukan bahwa implementasinya tidak efektif. Terdapat beberapa kemungkinan yang menjadi penyebabnya. Kemungkinan penyebab pertama, adalah tidak memadainya persiapan dalam implementasi suatu peraturan perundang-undangan, baik dari aspek sosialisasi, penyiapan struktur organisasi, kesiapan sumber daya manusia dari sisi kompetensinya, maupun dukungan pendanaanya. Kemungkinan kedua, karena adanya kelemahan dalam proses konsultasi publik, sehingga pihak-pihak yang seharusnya diminta pandangan dan aspirasinya (misalnya: pihak yang terkena dampak, serta pemangku kepentingan lainnya, termasuk interested parties) tidak mengetahui atau tidak dapat menerima ketentuan termaksud, akibatnya timbul pihak-pihak yang menentang pemberlakuannya, yang berakibat rendahnya kepatuhan dan akhirnya menjadikan peraturan perundang-undangan termaksud menjadi tidak efektif.

35 Banyak regulasi yang juga menciptakan beban yang tidak perlu, baik terhadap kelompok sasaran (targeted group) maupun non-kelompok sasaran (non-targeted group). Keadaan ini menunjukan bahwa pada saat pembentukan peraturan perundangan tidak cukup dilakukan identifikasi terhadap pihak-pihak yang potensial terkena dampak, serta tidak cukup dilakukan upaya-upaya untuk memitigasi dampaknya, sehingga ketika diberlakukan akan menimbulkan beban yang tidak perlu.

36 Banyaknya jumlah regulasi yang tidak proporsional (berlebihan) telah menciptakan ekonomi biaya tinggi. Ekonomi biaya tinggi jelas akan menambah biaya produksi, sehingga pada akhirnya produk atau jasa yang dihasilkan menjadi tidak kompetitif.

37 Disampaikan oleh Pesiden Joko Widodo pada Rapat Terbatas yang dilaksanakan pada Selasa, 12 Januari 2017 di Kantor Presiden, Jakarta. Lihat: Fabian Januarius Kuwado, Ini Fokus Jokowi dalam Reformasi Hukum Jilid II, http://nasional.kompas.com/read/ 2017/01/17/17104581/ ini.fokus.jokowi. dalam. reformasi. hukum.jilid.ii. (diakses 17 Januari 2017)

38 ibid.

39 ibid 
ditangani secara baik, yaitu; ${ }^{40}$ faktor dukungan politik, kualitas administrasi pemerintahan, dan kapasitas membuat, menerapkan, serta mengevaluasi kebijaksanaan-kebijaksanaan. ${ }^{41}$ Salah satu hasil evaluasi kebijaksanaan pemerintah yang telah dilakukan adalah deregulasi perda melalui harmonisasi peraturan terhadap 3.143 Perda guna peningkatan daya saing industri, iklim investasi, ekspor, wisata dan pertumbuhan ekonomi yang tinggi dan berkelanjutan ${ }^{42}$. Meskipundalamperkembangan terakhir, Putusan Mahkamah Konstitusi (MK) telah menyatakan bahwa kewenangan pemerintah untuk membatalkan Perda ${ }^{43}$ adalah bertentangan dengan konstitusi sehingga perlu disikapi agar tidak terjadi kekosongan hukum, dan tetap dapat menjalankan agenda reformasi hukum. Pemerintah perlu melanjutkan penataan regulasi melalui: ${ }^{44}$

\section{a. Evaluasi Seluruh Peraturan Perundang- Undangan}

Evaluasi seluruh peraturan perundangundangan perlu dilakukan mengingat kualitas regulasi saat ini masih rendah yang ditandai dengan masih adanya tumpang tindih dan disharmoni antar peraturan perundangundangan, baik yang bersifat vertikal maupun horizontal, jumlah regulasi juga masih dirasakan berlebihan serta tidak semuanya berdaya guna dan berhasil guna.

Evaluasi seluruh peraturan perundangundangan dilakukan melalui analisis dan evaluasi hukum untuk menilai norma hukum yang bersifat pengaturan (regeling), yang telah tertuang dalam peraturan perundangundangan dengan tujuan mendorong terjadinya proses reformasi regulasi sehingga peraturan perundang-undangan akan dapat berperan

40 Sjahrir, Good Governance di Indonesia Masih Utopia: Tinjauan Kritis Good Governance, Dalam Media Transparansi, edisi 14, November 1999, diakses dari www.transparansi.or.id/majalah/edisi14/14berita, (diakses 16 Mei 2005). Dalam tulisannya Sjahrir mengatakan bahwa faktor ketiga adalah kapasitas membuat, menerapkan serta mengevaluasi kebijaksanaan-kebijaksanaan khususnya di bidang ekonomi. Menurut penulis, bukan hanya kapasitas membuat, menerapkan serta mengevaluasi kebijaksanaan-kebijaksanaan di bidang ekonomi yang menjadi faktor pendukung good governance, tetapi kebijaksanaan-kebijaksanaan di semua bidang, baik ekonomi, politik, sosial, pertahanan dan keamanan, serta kultural.

41 Dalam literatur hukum administrasi, istilah "peraturan kebijaksanaan" di Indonesia biasa diartikan sebagai beleidsregels atau policy rules, atau disebut juga pseudo-wetgeving. Produkini tidakterlepas dari kaitan penggunaan fries ermessen, yaitu badan atau pejabat tata usaha yang bersangkutan merumuskan kebijaksanaannya itu dalam berbagai bentuk, seperti halnya peraturan, pedoman, pengumuman, surat edaran. Peraturan kebijaksanaan bukan peraturan perundang-undangan karena badan yang mengeluarkan peraturan kebijaksanaan tidak memiliki kewenangan pembuatan peraturan. Lebih jauh tentang ini lihat Philipus M Hadjon dkk, Pengantar Hukum Administrasi Indonesia, (Yogyakarta: Gajah Mada University Press, 1993) hlm.148. Namun demikian, penulis melihat bahwa apa yang dimaksud oleh Syahrir dalam tulisannya tersebut bisa diartikan sebagai "kebijaksanaan-kebijaksanaan dalam arti luas" yang mencakup tidak hanya beleidsregels, tetapi mencakup pula beschikking dan regeling.

42 Dna/Es, 2 Tahun Pemerintahan Jokowi-JK, Wiranto: Indeks Demokrasi Naik Jadi 73,12, http://setkab.go.id/2tahun-pemerintahan-jokowi-jk-wiranto-indeks-demokrasi-naik-jadi-7312/ (diakses 9 Agustus 2017).

43 Lihat Putusan MK dengan nomor perkara 137/PUU-XIII/2015 tekait uji materi Undang-Undang Nomor 23 Tahun 2014 tentang Pemerintahan Daerah.

44 Upaya penataan regulasi melalui: evaluasi seluruh peraturan perundang-undangan, penguatan pembentukan peraturan perundang-undangan, dan pembuatan database yang terintegrasi. Ketiga hal ini merupakan bagian dari program penataan regulasi agenda Revitalisasi Hukum Jilid II. Disampaikan oleh Pesiden Joko Widodo pada Rapat Terbatas yang dilaksanakan pada Selasa, 12 Januari 2017 di Kantor Presiden, Jakarta. Lihat: Fabian Januarius Kuwado, Ini Fokus Jokowi dalam Reformasi Hukum Jilid II, http://nasional.kompas.com/read/ 2017/01/17/17104581/ ini.fokus.jokowi. dalam. reformasi. hukum.jilid.ii. (diakses 17 Januari 2017) 
lebih optimal dalam mengatasi permasalahan penyelenggaraan kehidupan bernegara dan bermasyarakat sehingga dapat mendorong pelaksanaan pembangunan yang lebih efektif dan efisien.

Analisis dan evaluasi terhadap peraturan perundang-undangan dilakukan tidak hanya untuk memperbaiki materi hukum yang ada (existing), tetapi juga untuk perbaikan terhadap sistem hukum yang mencakup materi hukum, kelembagaan dan penegakan hukum, pelayanan hukum serta kesadaran hukum masyarakat. Hasil Analisis Evaluasi adalah rekomendasi terhadap status peraturan perundang-undangan yang ada, apakah perlu perubahan (revisi), penggantian (dicabut), atau dipertahankan. Analisis dan evaluasi peraturan perundang-undangan dilaksanakan melalui pembaruan hukum dengan tetap memerhatikan kemajemukan tatanan hukum yang berlaku dan pengaruh globalisasi sebagai upaya untuk meningkatkan kepastian dan perlindungan hukum, penegakan hukum dan
HAM. Oleh karena itu analisis dan evaluasi yang dilakukan haruslah berpijak pada nilai-nilai yang berasal dari budaya Indonesia sendiri. Landasan terpenting yang dipergunakan untuk melakukan evaluasi hukum Nasional tidak lain adalah Pancasila yang mengandung lima sila atau nilai dasar. Lima nilai dasar ini dianggap sebagai cerminan sejati dari budaya bangsa Indonesia yang plural. Artinya, lima nilai dasar itu menjadi sumber asas-asas hukum nasional, sekaligus basis ideal (spiritual) untuk menentukan suatu norma hukum. ${ }^{45}$

Analisis dan evaluasi dalam rangka penataan regulasi secara nasional dapat dilakukan dengan membentuk satuan tugas (satgas) khusus baik di level nasional, kementerian/lembaga, dan di pemerintah daerah, dalam koordinasi Kementerian Hukum dan HAM. Satgas ini perlu melibatkan berbagai pihak yang terkait dan kompeten seperti para analis, pejabat publik terkait, akademisi, peneliti, maupun praktisi hukum lainnya. Hal ini dapat digambarkan sebagai berikut:

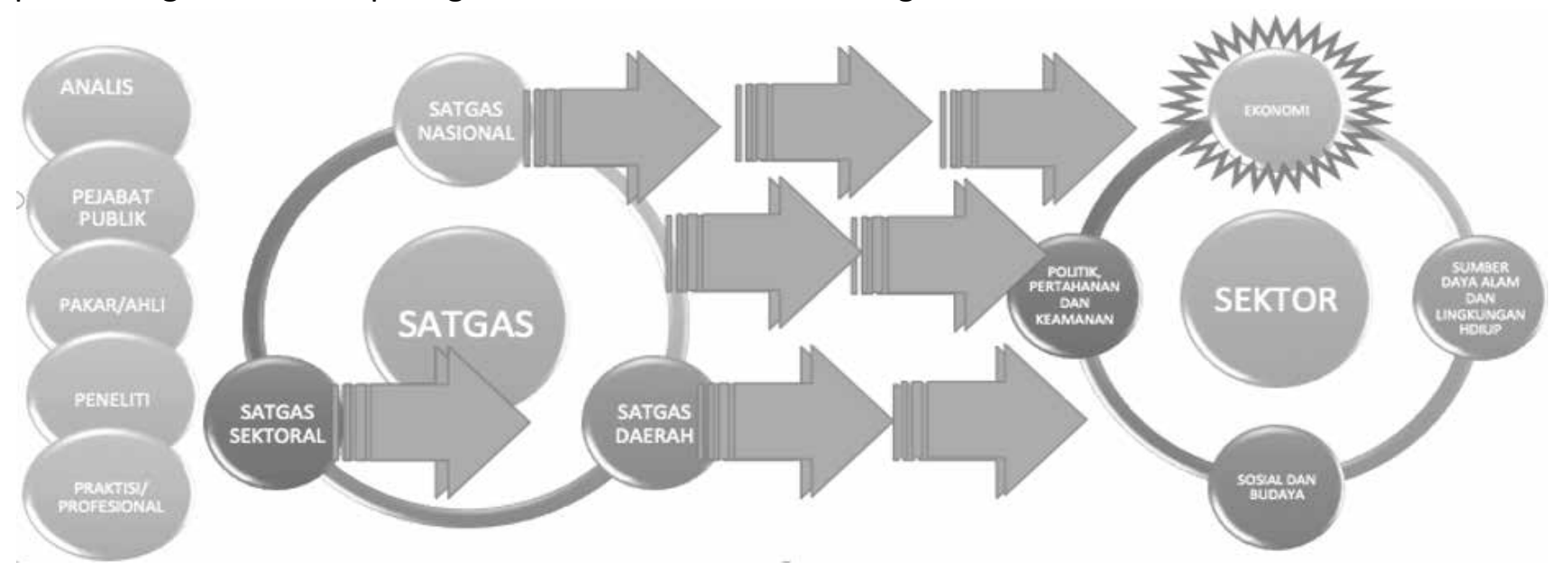

Gambar 2. Mekanisme Kerja Evaluasi Peraturan Perundang-Undangan

45 Disampaikan oleh Enny Nurbaningsih, selaku Kepala Badan Pembinaan Hukum Nasional dalam Pembukaan Focus Group Discussion "Evaluasi Hukum dan Proyeksi Pembangunan Hukum Nasional” yang dilaksanakan di Badan Pembinaan Hukum Nasional tanggal 9 November 2016. Lebih jauh lihat Pocut Eliza dkk, Dokumen Pembangunan Hukum Nasional Tahun 2016, (Jakarta: BPHN, 2016), hlm. 10. Bandingkan dengan Munir Fuady, Teori-Teori Besar Dalam Hukum, (Jakarta: Kencana, 2013), hlm. 141. Bandingkan juga dengan Jimly Asshiddiqie yang mengatakan bahwa dasar justifikasi terhadap suatu norma hukum adalah norma dasar. Lebih jauh lihat Jimly Asshiddiqie, Hukum Acara Pengujian Undang-undang, (Jakarta: Konstitusi Press, 2006), hlm. 1. 
Dalam melaksanakan analisis dan evaluasi ini perlu ada standar yang baku agar rekomendasi yang dihasilkan memiliki kualitas yang seragam. Oleh karena itu perlu mengembangkan instrumen penilaian yang mencakup: ${ }^{46}$ Pertama, kesesuaian antara jenis, hierarki, dan materi muatan; Kedua, Kejelasan Rumusan; Ketiga, materi muatan; Keempat, potensi disharmoni pengaturan; Kelima, efektivitas implementasi peraturan perundang-undangan. Penilaian lima dimensi ini bertujuan lebih komprehensif, tidak hanya secara normatif tetapi juga secara praktis. Standar inilah yang menjadi panduan dan arahan bagi para pelaksana teknis analisis dan evaluasi, baik yang berada di lingkungan Pemerintah Pusat dan Pemerintah Daerah. Selain itu, perlu juga dikembangkan penilaian biaya dan manfaat (cost and benefit analysis) CBA) agar persoalan-persoalan efisiensi dapat terjaring dan dirumuskan solusinya. ${ }^{47}$
b. Penguatan Pembentukan Peraturan Perundang-Undangan

Penguatan pembentukan peraturan perundang-undangan harus dilakukan karena masih terdapat penyelundupan isu-isu primordial, sektarian, kepentingan asing, dan ego sektoral dalam pembentukan peraturan perundang-undangan ${ }^{48}$, serta masih belum harmonisnya Undang-Undang Nomor 12 Tahun 2011 tentang Pembentukan Peraturan Perundang-undangan dengan Undang-Undang Nomor 23 Tahun 2014 tentang Pemerintah Daerah. Pada dasarnya penataan regulasi yang dilakukan saat ini merupakan sarana untuk menyeimbangkan trend globalisasi dan semangat kedaerahan dalam era otonomi daerah. Sebagaimana dikatakan oleh John Naisbitt, bahwa keinginan akan keseimbangan antara kesukuan dan universal selalu ada bersama kita. ${ }^{49}$ Proses legislasi harus mampu menangkap aspirasi dari masyarakat sekaligus mengontrolnya.Berbagaikebijakansertasumber

46 Instrumen penilaian ini digunakan dan dikembangkan oleh BPHN sejak tahun 2014, dan disebut sebagai metode 5 Dimensi (5D). Lebih jauh lihat http://bphn.go.id/news/2016041104071626/ ALUR-KERJA-ANALISIS-DANEVALUASI-HUKUM-NASIONAL (diakses 10 Agustus 2017) dan http://bphn.go.id/data/documents/lkip_ bphn_2016_full_-_new.pdf (diakses 11 Agustus 2017)

47 CBA adalah suatu metode analisis yang mengukur dan membandingkan seluruh manfaat/keuntungan yang akan diperoleh, serta biaya/beban/kerugian/konsekuensi yang harus ditanggung oleh semua penerima dampak dari suatu kebijakan/atau regulasi tertentu, beserta alternatif yang ada untuk digunakan membantu proses pengambilan keputusan. Lebih jauh lihat Ida Bagus Rahmadi Supancana, Sebuah Gagasan Tentang Grand Design Reformasi Regulasi Indonesia, (Jakarta: Penerbit Universitas Katolik Indonesia Atma Jaya, 2017) hlm. 73.

48 Pada dasarnya hukum nasional adalah suatu sistem. Sistem ini terdiri dari sejumlah unsur atau komponen atau fungsi/variabel yang selalu pengaruh-mempengaruhi, terkait satu sama lain oleh satu atau beberapa asas dan berinteraksi. Semua unsur/komponen/fungsi/variabel itu terpaut dan terorganisasi menurut suatu struktur atau pola yang tertentu, sehingga senantiasa saling pengaruh mempengaruhi dan berinteraksi. Asas utama yang mengaitkan semua unsur atau komponen hukum nasional itu ialah Pancasila dan UUD 1945, di samping sejumlah asas-asas hukum yang lain seperti asas kenusantaraan, kebangsaan, dan kebhinekaan. Sistem hukum nasional tidak hanya terdiri dari kaidah-kaidah atau norma-norma hukum belaka, tetapi juga mencakup seluruh lembaga aparatur dan organisasi, mekanisme dan prosedur hukum, falsafah dan budaya hukum, termasuk juga perilaku hukum pemerintah dan masyarakat. Lebih jauh lihat BPHN, Pola Pikir dan Kerangka Sistem Hukum Nasional Serta Rencana Pembangunan Hukum Jangka Panjang, (Jakarta: BPHN, 1995/1996) hlm.19.

49 Naisbitt, John, Global Paradox: Semakin Besar Ekonomi Dunia, Semakin Kuat Perusahaan Kecil, Terjemahan Budijanto, (Jakarta: Binarupa Aksara, 1994) hlm. 16. 
inputnya akan sangat bermanfaat bila dapat dikelola dengan baik dalam suatu manajemen legislasi yang tidak hanya sekedar demokratis, tetapi juga harus konstitusional. Politik hukum pembentukan peraturan perundang-undangan di Indonesia pada saat ini perlu mempertegas bahwa Pancasila sebagai dasar pembentukan, pengharmonisasian dan pengevaluasian peraturan perundang-undangan. Hal tersebut dimaksudkan untuk memperkecil kemungkinan penyelundupan isu-isu primordial, sektarian, kepentingan asing, dan ego sektoral dalam pembentukan peraturan perundangundangan. ${ }^{50}$ Perencanaan, pengharmonisasian, dan pengevaluasian peraturan perundangundangan oleh Kementerian Hukum dan HAM harus dilakukan secara aktif untuk semua peraturan perundang-undangan dengan parameter yang sama yaitu Pancasila, UUD NRI Tahun 1945, asas pembentukan peraturan perundang-undangan, dan asas materi muatan peraturan perundang-undangan.

Dalam sistem hukum nasional, peraturan perundang-undangan tingkat daerah merupakan bagian dari hukum nasional. Agar tercipta harmonisasi antara peraturan perundang-undangan tingkat pusat dengan peraturan perundang-undangan tingkat daerah maka perlu pengaturan mengenai pengharmonisasian, pembulatan, dan pemantapan konsepsi peraturan perundangundangan dalam skala yang lebih luas termasuk di dalamnya harmonisasi terhadap Peraturan
Menteri (Permen) dan Peraturan Daerah (Perda) agar terwujud peraturan perundang-undangan yang terintegrasi. ${ }^{51}$

c. Pembuatan Database Peraturan Perundang-undangan Yang Terintegrasi

Ada 2 (dua) alasan pentingnya kelengkapan database peraturan, yaitu: Pertama, memenuhi ketentuan perundang-undangan. Setiap peraturan perundang-undangan mewajibkan pemerintah untuk menempatkannya di lembaran negara. Kedua, database peraturan sangat diperlukan agar publik dapat dengan mudah mengetahui peraturan perundangundangan. Sebab, dengan teori fictie hukum, setiap warga negara diwajibkan untuk tahu dan memahami peraturan perundang-undangan. Namun lebih jauh dari kedua hal itu, pembuatan database yang terintegrasi perlu dilakukan untuk mengatasi ketidakseragaman database peraturan perundang-undangan yang dimiliki oleh lembaga-lembaga pemerintah. Hal ini menyebabkan belum tersedianya informasi yang akurat, mengenai status peraturan perundang-undangan sejak tahun 1945 - 2017, serta belum tersedianya informasi mengenai Peraturan Menteri dan Peraturan Daerah dalam database peraturan perundang-undangan yang terintegrasi. Penataan database hukum yang terintegrasi ini perlu dilakukan dengan memanfaatkan teknologi informasi. ${ }^{52}$

Database peraturan perundang-undangan merupakan sarana pendukung yang sangat vital

50 Lihat hasil rumusan Seminar Hukum Nasional dengan tema: Konstelasi Politik Dalam Pembentukan Peraturan Perundang-Undangan, yang dilaksanakan oleh BPHN di Jakarta 6 Oktober 2016.

51 Ibid

52 Berdasarkan Peraturan Presiden No.33 Tahun 2012 tentang Jaringan Dokumentasi dan Informasi Hukum Nasional (JDIH), Badan Pembinaan Hukum Nasional memiliki kewajiban dan kewenangan untuk pengembangan dan pengelolaan database peraturan perundang-undangan. Namun hingga saat ini, pengelolaan data peraturan perundang-undangan tersebut masih belum terintegrasi. 
bagi analisis dan evaluasi regulasi, harmonisasi, serta sinkronisasi peraturan perundangundangan. Dengan adanya database peraturan yang akurat dan terintegrasi maka proses analisis dan evaluasi regulasi yang bermasalah akan menjadi lebih mudah dan cepat. Begitu juga dengan proses harmonisasi dan sinkronisasi peraturan perundang-undangan untuk penguatan legislasi menjadi lebih cepat dan akurat.

Pada skala yang lebih luas, dengan tersedianya database yang baik maka informasi publik terbuka semakin lebar sehingga masyarakat dapat mengontrol setiap langkah dan kebijakan pemerintah, terutama dalam proses legislasi. Pemanfaatan teknologi informasi menjadi pilihan strategis untuk menguatkan fungsi pengawasan publik agar tidak terjadi penyimpangan. Keterbukaan informasi merupakan salah satu elemen penting dalam mewujudkan penyelenggaraan Negara yang terbuka dan tranparan untuk memberikan informasi kepada publik sesuai peraturan perundang-undangan yang berlaku. Dengan demikian maka masyarakat dapat ikut serta dalam melakukan pengawasan dalam proses legislasi. Pengawasan dan penilaian yang diberikan oleh masyarakat tersebut merupakan perwujudan dari kebebasan menyatakan pendapat sebagai salah satu ciri negara hukum Pancasila.

Pemanfaatan teknologi informasi dapat dilakukan mulai dari tahap pra legislasi hingga pasca legislasi sebagaimana gambar berikut: ${ }^{53}$

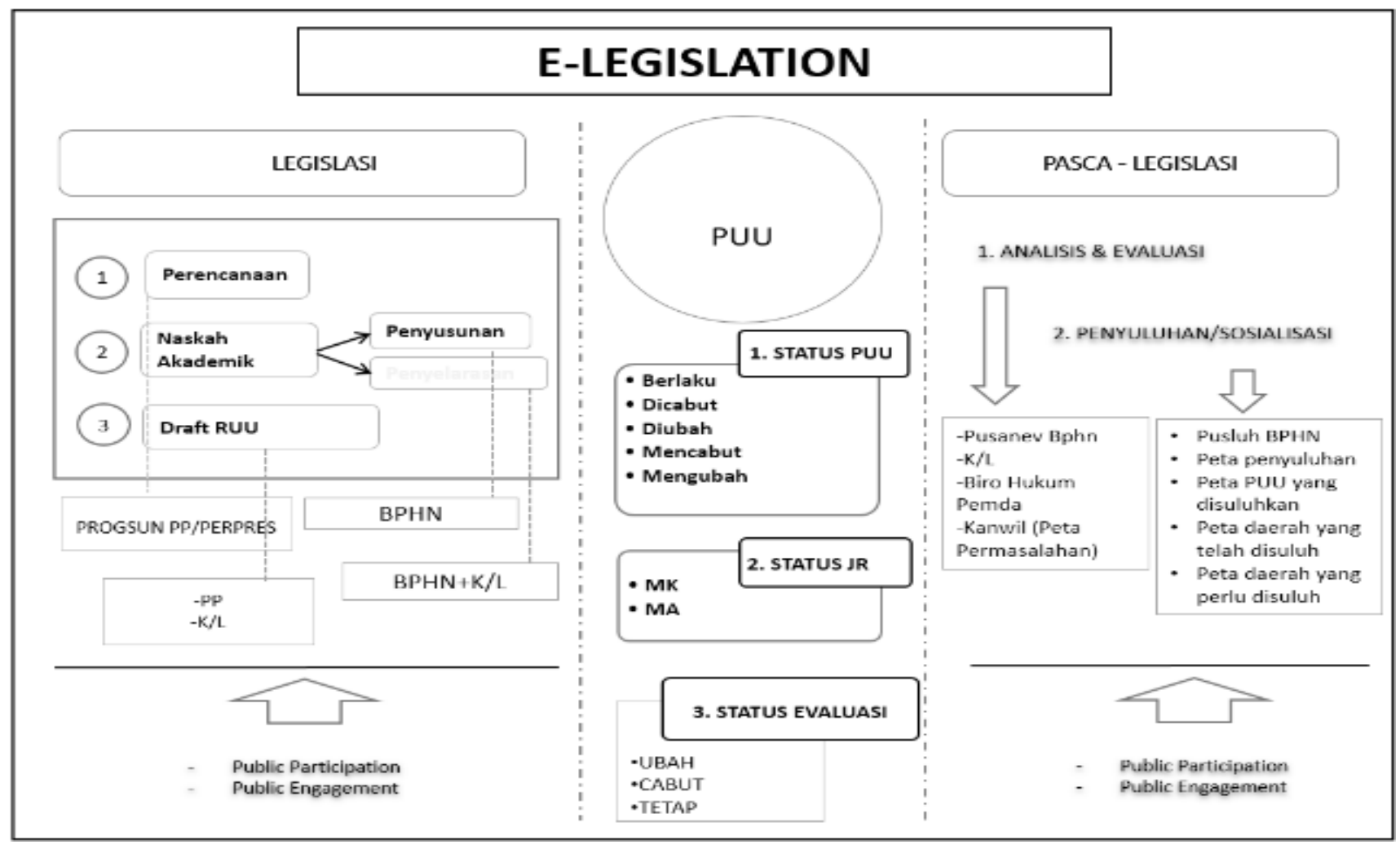

Gambar 3. Penataan Database Peraturan Perundang-Undangan Menuju E-Legislasi

53 Bandingkan dengan Arfan Faiz Muhlizi, Membangun E-Legislasi di Indonesia, http:// www. rechtsvinding. bphn. go.id / view/ view_online.php?id=244 (diakses 10 Agustus 2017). 
Dengan pola di atas maka Selama ini, kesulitan terbesar dalam melakukan pengawasan oleh masyarakat terhadap kinerja pemerintah adalah "mengumpulkan informasi yang selengkap-lengkapnya". Proses ini paling sulit dilakukan tanpa dibantu oleh teknologi informasi dan dukungan regulasi bagi akses publik. Oleh karena itu maka dukungan kebijakan yang mewajibkan adanya penggunaan teknologi informasi dalam menjalankan fungsi pemerintahan, terutama dalam proses legislasi menjadi faktor determinan keberhasilan pengawasan dan penilaian yang dilakukan oleh masyarakat. Meningkatnya pengetahuan masyarakat mengenai proses legislasi dapat meningkatkan minat dan keinginan masyarakat untuk berperan serta dan berpartisipasi dalam proses penyelenggaraan pemerintahan sesuai dengan kapasitas masing-masing.

\section{Penutup}

Dari uraian di atas dapat disimpulkan bahwa: pertama, Pembangunan ekonomi nasional dengan pendekatan teori hukum integratif perlu dilakukan agar kebijakan yang dikeluarkan untuk memudahkan usaha dan meminimalkan risiko berusaha dapat diimbangi dengan penguatan peran hukum yang bukan sekedar sebagai pemberi fasilitas kemudahan berusaha, tetapi juga memberikan perlindungan bagi persaingan usaha yang tidak sehat di tengah iklim ekonomi dunia yang cenderung liberal agar tidak larut dalam pusaran pasar bebas. Teori hukum integratif memberikan pencerahan mengenai relevansi Pancasila dan arti penting hukum dalam menjalankan fungsi stabilitas (stability) untuk menyeimbangkan dan mengakomodasi kepentingan-kepentingan yang saling bersaing. Teori hukum integratif menempatkan Pancasila sebagai bintang pemandu agenda penataan regulasi untuk menciptakan ease of doing business agar tidak menabrak nilai-nilai dasar kehidupan berbangsa dan bernegara, dan menjaga agar tidak tumbuh menjadi sistem ekonomi liberal. Penciptaan EODB harus memperhatikan tujuh ciri konstitusional pembangunan ekonomi yaitu: 1) perekonomian bertujuan untuk mencapai kemakmuran bersama seluruh rakyat, 2) keikutsertaan rakyat dalam pemilikan dan proses proses produksi 3) perekonomian dijalankan dengan menggunakan mekanisme pasar yang berkeadilan dengan memberikan peran serta kewenangan negara untuk intervensi jika terjadi kegagalan pasar, 4) peran Negara harus dijamin dalam hal perencanaan ekonomi nasional, dalam membentuk dan menegakkan pelaksanaan Undang-undang, dan dalam hal melaksanakan program pelayanan dan pemberdayaan masyarakat, pembebasan pajak, pemberian subsidi dan lainnya, 5) BUMN menguasai cabang-cabang produksi yang penting dan yang menguasai hajat hidup orang banyak, 6) koperasi harus diwujudkan dalam semangat kebersamaan dengan BUMN dan swasta, serta sebagai badan usaha ekonomi rakyat, 7) perekonomian nasional haruslah merupakan perwujudan dari kemitraan yang sejajar antara koperasi, BUMN dan swasta.

Kedua, Pemerintah perlu melakukan penataan regulasi melalui 3 (tiga) langkah sebagai berikut: 1) evaluasi seluruh peraturan perundang-undangan, 2) penguatan pembentukan peraturan perundang-undangan, dan 3) pembuatan database peraturan perundangundangan yang terintegrasi. Evaluasi seluruh peraturan perundang-undangan perlu dilakukan mengingat kualitas regulasi saat ini masih rendah yang ditandai dengan masih adanya tumpang tindih dan disharmoni antar peraturan 
perundang-undangan, baik yang bersifat vertikal maupun horizontal, jumlah regulasi juga masih dirasakan berlebihan serta tidak semuanya berdaya guna dan berhasil guna. Penguatan pembentukan peraturan perundangundangan harus dilakukan karena masih terdapat penyelundupan isu-isu primordial, sektarian, kepentingan asing, dan ego sektoral dalam pembentukan peraturan perundangundangan, serta masih belum terintegrasinya Undang-Undang Nomor 12 Tahun 2011 dengan Undang-Undang Nomor 23 Tahun 2014 tentang Pemerintah daerah. Pembuatan database yang terintegrasi perlu dilakukan untuk mengatasi ketidakseragaman database peraturan perundang-undangan tingkat pusat yang dimiliki oleh lembaga-lembaga pemerintah agar tersedia informasi yang akurat, mengenai status peraturan perundangundangan, baik tingkat pusat maupun daerah. Database peraturan perundang-undangan merupakan sarana pendukung yang sangat vital bagi analisis dan evaluasi regulasi, harmonisasi, serta sinkronisasi peraturan perundangundangan. Dengan adanya database peraturan yang akurat dan terintegrasi maka proses evaluasi regulasi yang bermasalah akan menjadi lebih mudah dan cepat. Begitu juga dengan proses harmonisasi dan sinkronisasi peraturan perundang-undangan untuk penguatan legislasi menjadi lebih cepat dan akurat, serta membuka peran serta masyarakat untuk mengontrol setiap langkah dan kebijakan pemerintah yang mendukung EODB.

\section{Daftar Pustaka}

\section{Buku}

Asshiddiqie, Jimly. Hukum Acara Pengujian Undangundang, (Jakarta: Konstitusi Press, 2006)
Atmasasmita, Romli. Pengantar Hukum Kejahatan Bisnis, (Jakarta: Prenada Media, 2003)

Atmasasmita, Romli. Teori Hukum Integratif: Rekonstruksi Terhadap Teori Hukum Pembangunan dan Teori Hukum Progresif, (Yogyakarta: Genta Publishing, 2012)

Bashri, Yanto (ed). "Mau Ke Mana Pembangunan Ekonomi Indonesia. Prisma Pemikiran Prof. Dr. Dorodjatun Kuntjoro-Jakti. (Jakarta: Predna Media, 2003)

BPHN, Pola Pikir dan Kerangka Sistem Hukum Nasional Serta Rencana Pembangunan Hukum Jangka Panjang, (Jakarta: BPHN, 1995/1996)

Dworkin, Ronald. Legal Research, (Daedalus: Spring, 1973)

Eliza, Pocut dkk. Dokumen Pembangunan Hukum Nasional Tahun 2016, (Jakarta: BPHN, 2016),

Fuady, Munir. Teori-Teori Besar Dalam Hukum, (Jakarta: Kencana, 2013)

Hadjon, Philipus $\mathrm{M}$ dkk. Pengantar Hukum Administrasi Indonesia, (Yogyakarta: Gajah Mada University Press, 1993)

Hartono, CFG Sunaryati. Globalisasidan Perdagangan Bebas, (Jakarta: BPHN Departemen Kehakiman, 1996)

Kusumaatmadja, Mochtar. Konsep-konsep Hukum Dalam Pembangunan, (Bandung: Alumni, 2002)

Manullang, E Fernando M (editor). Selayang Pandang Sistem Hukum di Indonesia, Cetakan ke 2, (Jakarta: Penerbit Kencana, 2016)

Mertokusumo, Soedikno. Mengenal Hukum: Suatu Pengantar, Cetakan Kedua, Edisi ke empat, (Yogyakarta: Penerbit Liberty, 1999)

Mertokusumo, Sudikno dan A. Pitlo. Bab-bab tentang Penemuan Hukum, (Yogyakarta: Citra Adtya Bakti, 1993)

Mok, M.R. Economisch recht dalam Problemen van Wetgeving, (Kluwer: Deventer, 1982)

Naisbitt, John. Global Paradox: Semakin Besar Ekonomi Dunia, Semakin Kuat Perusahaan Kecil, Terjemahan Budijanto, (Jakarta: Binarupa Aksara, 1994)

Napitupulu, B. Joint Ventures di Indonesia. (Jakarta: Erlangga, 1975)

Radjagukguk, Erman, Hukum Investasi di Indonesia, (Jakarta: FH Univ Al Azhar Indonesia, cetakan pertama, 2007)

Rusdin. Bisnis Internasional dalam Pendekatan Praktik. Jilid 1. (Bandung: Alfabeta, 2002)

Saragih, Barita. Tantangan Hukum atas Aktivitas Internet, Kompas, Minggu, 9 Juli 2000 
Soekanto, Soerjono dan Sri Mamudji. Peranan dan Penggunaan Perpustakaan di Dalam Penelitian Hukum, (Jakarta: Pusat Dokumentasi Hukum Fakultas Hukum Universitas Indonesia, 1979)

Tjakrawerdaja, Subiakto. Menunggu UU Induk Mengenai Perekonomian Nasional, Reform Review (Jurnal untuk Kajian dan Pemetaan Krisis), Volume II Nomor 1 April-Juni 2008

Sunanto, Hatta et.all. Menggeser Pembangunan Memperkuat Rakyat, Emansipasi dan Demokrasi Mulai dari Desa, (Yogyakarta: Lapera Pustaka Utama, 2000)

Supancana, Ida Bagus Rahmadi. Sebuah Gagasan Tentang Grand Design Reformasi Regulasi Indonesia, (Jakarta: Penerbit Universitas Katolik Indonesia Atma Jaya, 2017)

Sutedi, Adrian. Hukum Perizinan Dalam Sektor Pelayanan Publik, cetakan ketiga, (Jakarta: Sinar Grafika, 2015)

\section{Makalah/Artikel/Laporan/Hasil Penelitian}

BPHN, Hasil Rumusan Seminar Hukum Nasional dengan tema: Konstelasi Politik Dalam Pembentukan Peraturan Perundang-Undangan, yang dilaksanakan oleh BPHN di Jakarta 6 Oktober 2016

DAPP-BAPPENAS, "Pemetaan Hasil Identifikasi terhadap undang-undang Sektor yang Berpotensi Bermasalah", disampaikan pada workshop koordinasi strategis analisa peraturan perundang-undangan Jakarta, 5 Desember 2012.

Lev., Daniel S. "Pemulihan Negara Hukum", Tempo, 6 Januari 2002.

Nurbaningsih, Enny. "Evaluasi Hukum dan Proyeksi Pembangunan Hukum Nasional", makalah disampaikan dalam Focus Group Discussion Pembangunan Hukum Nasional yang dilaksanakan di Badan Pembinaan Hukum Nasional tanggal 9 November 2016.

Subhan, Hadi. mengutip Latif Adam, Prioritas Pengembangan Hukum Di Bidang Investasi, makalah pada harmonosasi dan sinkronisasi BPHN, Oktober 2008.

Sulistyono, Adi, Pembangunan Hukum Ekonomi Untuk Mendukung Pencapaian Visi Indonesia 2030, Makalah disampaikan pada Pidato Pengukuhan Guru Besar Hukum Ekonomi dalam Sidang Senat Terbuka Universitas Sebelas Maret Surakarta, 17 Nopember 2007.
Zaidun, Muchammad. Prinsip-prinsip Hukum Internasional Penanaman Modal Asing di Indonesia, (Ringkasan Disertasi), Program Pasca Sarjana Universitas Airlangga, 2005

\section{Internet}

Ahm/YK/WP, Tumpang-Tindih Regulasi Hambat Kemudahan Usaha, http://www.koranjakarta.com/tumpang-tindih-regulasi-hambatkemudahan-usaha/ (diakses 8 Agustus 2017)

Dna/Es, 2 Tahun Pemerintahan Jokowi-JK, Wiranto: Indeks Demokrasi Naik Jadi 73,12, http://setkab. go.id/2-tahun-pemerintahan-jokowi-jk-wirantoindeks-demokrasi-naik-jadi-7312/ (diakses 9 Agustus 2017)

Ibnu Hariyanto. Menkum HAM Ungkap Penyebab Banyak UU Masih Tumpang Tindih, https://news. detik.com/berita/d-3334692/menkum-hamungkap-penyebab-banyak-uu masih- tumpangtindih (diakses 8 Agustus 2017)

Kuwado, Fabian Januarius, Ini Fokus Jokowi dalam Reformasi Hukum Jilid II, http://nasional. kompas.com/read/ 2017/01/17/17104581/ ini. fokus.jokowi. dalam. reformasi. hukum.jilid.ii. (diakses 17 Januari 2017)

Muhlizi, Arfan Faiz. Membangun E-Legislasi di Indonesia, http:// www. rechtsvinding. bphn. go.id / view/ view_online.php?id=244 (diakses 10 Agustus 2017)

Sjahrir, Good Governance di Indonesia Masih Utopia: Tinjauan Kritis Good Governance, Dalam Media Transparansi, edisi 14, November 1999, http://www.transparansi.or.id/ majalah/ edisi14/14berita, (diakses 16 Mei 2005)

http://eodb.ekon.go.id/ (dikases 17 Juni 2017) http://www.bkpm.go.id/id/artikel/readmore/ usaha-pemerintah-indonesia-dalammeningkatkan-kemudahan-berusaha, (diakses 8 Agustus 2017).

http://bphn.go.id/news/2016041104071626/ ALUR-KERJA-ANALISIS-DAN-EVALUASI-HUKUMNASIONAL (diakses 10 Agustus 2017) dan http:// bphn.go.id/data/documents/lkip_bphn_2016_ full___new.pdf (diakses 11 Agustus 2017) 
"Halaman ini dikosongkan" 